\title{
Uważność (mindfulness) w pracy socjalnej z osobami uzależnionymi
}

Medytacja jest dla bardzo wielu osób pracujących w ramach 12 kroków integralnym elementem ich drogi do wolności od uzależnienia. Ważne jest, aby ukazać, w jaki sposób praktykowanie uważności może przenikać życie codzienne. Wyróżnimy poniżej oddech i teraźniejszość jako kluczowe elementy praktyki mindfulness. Wydaje się, że szczególne znaczenie $\mathrm{w}$ walce $\mathrm{z}$ uzależnieniem ma metoda Stanleya Blocka - Mind-Body Bridging - którą przedstawimy w drugiej części artykułu. Zmysłowe doświadczenie świata, wrażliwość na proste dźwięki i dotyk mogą stać się dla praktykujących 11. krok prawdziwą medytacją codzienności. Metoda ta nie wymaga żadnych kosztów ani ukończenia specjalistycznych kursów. Wystarczy być. Tylko tyle i aż tyle.

Godność człowieka odsyła nas do pewnego fundamentalnego, lecz tajemniczego doświadczenia. „Kim jestem?” - oto kluczowe pytanie,

1 Paweł Koza - dr filozofii, coach; tutor w Fundacji Dorastaj z Nami; twórca projektu PhiloCoaching. Przygotowuje pracę magisterską z pracy socjalnej w Zakładzie Socjologii Stosowanej i Pracy Socjalnej U]. 
które w praktyce pomocowej winno być bardzo mocno wyrażone. „Kim jestem ja, który potrzebuję pomocy?”, „Kim jestem ja, który pełnię funkcję pracownika socjalnego?". Szybką odpowiedź na te pytania, które ludzkość stawia sobie od wieków, podpowiadają nam role społeczne, które pełnimy. „Jestem uzależniony”, „Jestem chory”, "Jestem narkomanem". Takie odpowiedzi przychodzą klientom dość szybko z tego względu, że są częścią narracji społecznej.

Poznanie drugiego człowieka jako członka społeczności odbywa się często w sposób niezwykle powierzchowny; dążymy raczej do tego, by jak najszybciej przykleić komuś „etykietkę” (label). Takie etykiety, które możemy nazwać znaczącymi określeniami, mają szczególnie doniosłe znaczenie w odniesieniu do grup wykluczonych. W przypadku osób zmarginalizowanych dochodzi bowiem do silnej identyfikacji z rolą społeczną. Taki proces można sprecyzować poprzez formułę jestem tym (chorym, narkomanem, uzależnionym). Owa identyfikacja ma charakter pewnego filtra percepcyjnego. Człowiek wówczas postrzega świat inaczej, z odmiennej perspektywy - z punktu widzenia chorego, uzależnionego, narkomana.

$\mathrm{W}$ tym miejscu mamy jednak do czynienia z powstaniem fałszywej świadomości. Poznanie i tożsamość to bowiem dwie odrębne sfery naszego człowieczeństwa. Fałszywa świadomość polega na tym, że przestajemy rozróżniać percepcję i tożsamość. Sposób, w jaki jesteśmy postrzegani, staje się naszą tożsamością. Skoro ktoś nadużywa substancji psychoaktywnych, twierdzi, że „to jestem ja, uzależniony”. Inni traktują go jak alkoholika czy narkomana, więc za kogo więcej mógłby się uważać?

Wykluczenie samo w sobie nie jest tożsamością, lecz oznacza pewien ogólny schemat percepcyjny, który najkrócej można scharakteryzować jako „bycie poza”. „Prawdziwe życie toczy się gdzie indziej” może stwierdzić klient za Jaromilem, bohaterem Milana Kundery². Wykluczony może tylko egzystować na granicy wegetacji, traktu- 
jąc swoje życie jako niemal niewarte przeżycia. Prawdziwe życie może jedynie „podglądać”, obserwując celebrytów, przeklinając polityków czy zazdroszcząc milionerom. Jednak w tym podglądaniu osoba wykluczona jeszcze boleśniej odczuwa swój status. „Oni” są „W środku”, „W sercu społeczności”, mając dostęp do dóbr i prestiżu. „Ja jestem gdzieś na śmietniku”, „Jestem włóczęgą”, który nie ma swojego miejsca ${ }^{3}$. Taka narracja, swoisty dialog wewnętrzny, który toczy się w umyśle osoby wykluczonej, choć w swej istocie jest tylko „sposobem percepcji” otaczającej rzeczywistości, rości sobie prawo do odniesień tożsamościowych. „Jestem zerem” - to często kulminacja tego myślowego procesu. W ten sposób punkt widzenia, ów szczególny filtr percepcyjny, staje się odpowiedzią na pytanie „kim jestem?”.

Niestety pracownik socjalny często podziela, a najczęściej jeszcze wzmacnia tę fałszywą świadomość. Występuje w roli profesjonalisty, który reprezentuje ową „zdrową tkankę społeczną”. Pracownik socjalny postrzega klienta przez ten sam "filtr percepcyjny” i traktuje go jako „alkoholika” czy „narkomana”. Co więcej, często uznanie swojej rozpaczliwej sytuacji przez klienta jest traktowane jako „niezbędna obiektywizacja”. Nie można się dziwić takiej strategii, gdyż do zaistnienia komunikacji między klientem a pracownikiem socjalnym niezbędna jest wspólnota (communio). Jednak tę wspólnotę najczęściej tworzy się poprzez podzielanie wspólnego filtra percepcyjnego, w którym klient uznaje siebie za „pijaka” albo za „ćpuna”, a pracownik socjalny traktuje go jako „alkoholika” czy „narkomana”. W ten przedziwny sposób spotykają się - i wspólnie tworzą ramy wykluczenia.

3 Por. Z. Bauman, Clobalizacja, Warszawa 2000; Z. Bauman, Życie na przemiat, Kraków 2004. 


\section{Mindfulness jako narzędzie reintegracji}

Prawdziwa tożsamość klienta odsłoni się przed nim wówczas, gdy doświadczy on swojego prawdziwego „ja”. Celem pracowników socjalnych winno być dostarczenie mu narzędzi, aby mógł eksplorować przestrzeń własnego wnętrza. Takim użytecznym narzędziem jest z pewnością praktykowanie uważności - mindfulness. Oddzielenie naszych myśli i sposobu, w jaki postrzegamy rzeczywistość (filtru percepcyjnego), od tego, kim jesteśmy, może się dokonać wyłącznie w oparciu o wgląd w funkcjonowanie ludzkiego umysłu.

Uważność (mindfulness) ma swój początek w duchowości zmierzającej do wglądu w istotę rzeczywistości. Na fali kontrkultury lat sześćdziesiątych bardzo wielu Europejczyków zaczęło uważać medytację opartą na uważności jako integralną część własnego rozwoju duchowego. Uważność stała się podstawą programów terapeutycznych takich jak Mindfulness-Based Stress Reduction (autorstwa Jona Kabat-Zinna) czy Mind-Body Bridging (którego autorem jest Stanley Block). Badania naukowe potwierdziły jej skuteczność w zakresie terapii depresji ${ }^{4}$. Wydaje się, że również w pracy socjalnej z osobami uzależnionymi uważność może okazać się niezwykle wartościowym narzędziem.

\section{Umysł początkującego}

Życie społeczne zakłada pewną określoną stratyfikację, gdzie jedni na drabinie społecznej są położeni wyżej, a inni niżej. Praca socjalna zwykle reprodukuje tę społeczną hierarchię, zakładając, że

4 Por. M. Williams i in., Świadoma droga przez depresje, tłum. P. Listwan, Warszawa 2009. 
pomaga osobom $\mathrm{z}$,nizin społecznych”. Tymczasem w praktykowaniu uważności każdy jest „początkującym”. Nie ma lepszych i gorszych, bardziej i mniej zaawansowanych. Rzeczywistość bowiem za każdym razem nas zadziwia i należy do niej podejść tak, jakby się ją widziało pierwszy raz. Shunryū Suzuki napisał: „W umyśle początkującego jest wiele możliwości, w umyśle eksperta tylko parę" 5 .

Kiedy pomyślimy o świecie przez pryzmat praktykowania uważności, wówczas dostrzeżemy, że wszyscy jesteśmy początkującymi. W tym momencie nie możemy już właściwie mówić o wykluczeniu. W procesie medytacji nie ma wykluczonego i milionera, lecz każdy zaczyna od tego samego momentu. Każdego dnia - gdy praktykuje uważność, obserwując kwiaty, myjąc zęby czy też siedząc na poduszce medytacyjnej - zaczyna od początku. Ów początek ma kilka wymiarów. Po pierwsze - w czasie. Każdy proces uważności zaczyna się od „punktu zero”, który wyznacza na przykład gong w sali medytacyjnej. Po drugie, początek w znaczeniu braku hierarchii. Nie ma tutaj lepszych i gorszych, wszyscy są równi. I po trzecie - początek w nas. Zaczynamy bowiem medytować, spoglądając na świat z pewnego szczególnego punktu widzenia, docieramy do tego, co najbardziej źródłowe, najbardziej pierwotne w naszym ,ja”.

A zatem uważność sprawia, że klient może zmienić punkt widzenia, dotrzeć do początku, do tego, co najbardziej podstawowe. W ten sposób wychodzi poza dualny podział: in-out, włączenie-wykluczenie, bogaty-biedny itp. W zamian zyskuje inną optykę. Może odkryć w sobie tę świętą przestrzeń obecności, dostępną dla każdego człowieka, który tylko otworzy się na bycie - bez względu na jego pozycję społeczną i posiadany dochód.

5 S. Suzuki, Umysł zen, umysł początkującego, tłum. J. Dobrowolski, A. Sobota, Jaworze 2010, s. 32. 


\section{Oddech}

Niezwykle istotny w procesie praktykowania uważności jest oddech. Wydaje się, że ma on również kluczowe znaczenie w odzyskiwaniu wglądu w swoją prawdziwą tożsamość. Jon Kabat-Zinn trafnie zauważył, że „z każdym wdechem pijemy powietrze, z każdym wydechem oddajemy je światu"6. W obserwacji oddechu docieramy do owego początku. Gdy oddychamy, uczestnicząc w niezwykłym procesie życia, jesteśmy wszyscy równi. Świadomy oddech jest w pełni inkluzyjny, nikogo nie wyklucza.

Świadomość oddechu wydaje się niezwykle istotna dla procesu reintegracji tożsamości. Oddech odsyła nas nie tylko poza społeczne struktury, lecz również poza granice woli. Nie jest bowiem napędzany naszym chceniem lub niechceniem. Używając języka fizjologii, możemy powiedzieć, że tego typu procesy reguluje pień mózgu. Coś tajemniczego w nas powoduje, że oddychamy oraz że bije nasze serce. Warto postawić pytanie: „Kto oddycha?”, skoro nasza wola nie ma $\mathrm{w}$ tej materii nic do powiedzenia...

Świadomość oddechu może mieć również kluczowe znaczenie dla procesu reintegracji uzależnień. Poprzez nią nasz klient może abstrahować od pozycji społecznej, jaką zajmuje, i od zasobów finansowych, jakie są w jego posiadaniu. Co ważne - odrywa się również od myśli, a wraca do prostej świadomości oddechu. Może wówczas po prostu być. Nie w obrębie takiej czy innej koncepcji empowermentowej czy strukturalnej, lecz być po prostu - jako człowiek, którego prawdziwa istota dalece przekracza i wyprzedza myśl.

W samo pojęcie pracy socjalnej wpisana jest pewna dynamika, ruch. Wiele dyscyplin ma ukryte w nazwie słowo logos - filo-logia, psycho-logia, socjo-logia, bio-logia. Ów logos (gr. 入óyos - „zasada”,

6 J. Kabat-Zinn, Praktyka uważności dla poczq̨tkujących, tłum. J. P. Listwan, Warszawa 2014, s. 19. 
„słowo”, „rozum”) odnosi nas do pewnej stałości, niezmienności, ostatecznej zasady świata. Dziedzina social work jest natomiast „pracą", a więc działaniem, pewną akcją, wręcz czynnością, w której refleksja oparta o niezmienny logos wydaje się stać na drugim planie.

W naszych rozważaniach przyjmujemy, że praca socjalna - podobnie jak inne dyscypliny - winna oprzeć się na tym, co stanowi logos społecznego współistnienia. Ów logos można rozumieć w dwóch wymiarach: uniwersalnym - odnoszącym się do każdego członka społeczności ze względu na jego człowieczeństwo - i jednostkowym wprowadzającym ład i porządek w codzienne życie pojedynczego człowieka w konkretnym środowisku, w jakim się znajduje. W tym miejscu skupimy się na „logosie jednostkowym” - twierdzimy, że jest nim uważność, wprowadza ona bowiem ład i porządek (logos) w życie klienta zmagającego się z uzależnieniem w tym konkretnym momencie jego życia.

Oddech może stać się tą „,kotwicą”, która zaczepia klienta w chwili obecnej. W pracy socjalnej często podkreśla się, że klient „musi coś zrobić ze swoim życiem". Tymczasem w uważności chodzi o coś zupełnie innego - jak podkreślają jej nauczyciele, kluczową zasadą jest being before doing. Najpierw klient winien „być”, zaczepić się w rzeczywistości, a dopiero w następnej kolejności „coś robić”. Wszelka jego aktywność ma bowiem płynąć właśnie z tych momentów ciszy i zakotwiczenia w chwili obecnej, a dopiero później ma on podejmować działanie.

Klient często znajduje się w stanie rozedrgania, stresu i napięcia, które prowadzą do nieadekwatnego działania. Taki kształt życia wewnętrznego jest najczęściej przeszkodą w pędzeniu uporządkowanej egzystencji, w której istnieje pewien logos. Ów wewnętrzny stan można porównać do szklanki mętnej wody ${ }^{7}$. Gdy mieszamy wodę, cały czas utrzymujemy jej mętność, a wręcz ją wzmacniamy. 
Gdy powstrzymamy się od działania, wówczas będzie czysta. Skupienie uwagi przez krótszy lub dłuższy czas na oddechu zatrzymuje działanie i kołowrotek myśli wzmacniający patową sytuację. Praktykowanie tego na co dzień prowadzi do innego punktu widzenia. Pozornie nie zmienia się nic, a jednak pojawia się przestrzeń dla nowej perspektywy.

Oddech jest tym, z czego klient nie jest wykluczony. To bardzo ważne - oddech jest w pełni inkluzyjny, nie jest zarezerwowany tylko dla zamożnych. To jest bowiem źródłowa przestrzeń życia, która nie zna takich terminów jak włączenie i wykluczenie. Świadomość oddechu jest dostępna dla klienta w każdej chwili. Oddech jest bardzo bliski człowieczeństwu, świadomość skierowana na oddech pozwala oderwać się od myślenia o sobie wyłącznie w kategoriach in-out. Świadomość oddechu przynosi również doświadczenie szczególnej wspólnoty. Zarówno pracownik socjalny, jak i klient oddychają, nie ma tutaj lepszych i gorszych, przedstawicieli pomocy społecznej i klientów. Świadomość oddechu prowadzi do jedności uczestnictwa w tej samej rzeczywistości przez klienta i pracownika socjalnego.

\section{Teraźniejszość}

Świadomość oddechu sprowadza zarówno klienta, jak i pracownika socjalnego do chwili obecnej. Jedyna bowiem dostępna dla nas rzeczywistość to teraźniejszość. Sytuacja życiowa klientów jest często bardzo skomplikowana, co sprzyja rozpamiętywaniu katastrofalnych wydarzeń z przeszłości lub wyzwala obawy przed przyszłymi wyzwaniami i trudnościami. Konfrontacja z dziejącą się właśnie realnością - uzależnieniem, brakiem pracy, biedą, odebraniem dzieci, bezdomnością - wydaje się często przekraczać siły człowieka. Dlatego tak kuszącym rozwiązaniem jest zatopienie się w dobrze znanych rozważaniach o przeszłych porażkach albo oswojonych już lękach i marzeniach odnoszących się do przyszłości. 
Praca socjalna oparta na uważności pokazuje inną drogę. Świadomość oddechu jest „bramą do teraźniejszości”. Klient zyskuje dzięki temu użyteczne narzędzie, aby wyjść poza odziedziczony po naszych przodkach mechanizm walki i ucieczki. Doświadczenie tego, jak oddech wypełnia i opuszcza ciało, odczucia jamy brzusznej z tym związane oraz nozdrzy, przez które przepływa powietrze - to wszystko sprawia, że klient zyskuje nowy punkt widzenia ${ }^{8}$. Jego sytuacja życiowa się nie zmienia, lecz on może popatrzeć na nią z nowej, nieznanej dotąd perspektywy.

Świadomość oddechu, którą w pewnych momentach swojego życia praktykuje klient, określimy za Diane Eshin Rizzetto jako chwilę „nie-działania” i „nie-wiedzenia”. Oczywiście że kontrakt socjalny wymaga stawiania konkretnych celów, wyznaczania terminów, wzmacniania motywacji itp. Proponujemy jednak, aby w ten zadaniowo-wolitywny model wpleść właśnie momenty „nie-działania” i „nie-wiedzenia”. Świadomość oddechu, zwłaszcza praktykowana regularnie, wprowadza w życie taką nową perspektywę, w której nie tyle coś robimy, ile jesteśmy. To dosłownie i metaforycznie przerwa, w której zawieszone zostają nawykowe reakcje. Nasz klient może wówczas dokonać ewaluacji swoich mechanizmów reagowania. Teraźniejszość przynosi nam za każdym razem możliwość nowego spojrzenia, a najlepiej służy temu owa przerwa „nie-działania” i „nie-wiedzenia”.

Dlaczego tak ważna dla pracy socjalnej jest doświadczana wraz z każdym oddechem teraźniejszość? Dzieje się tak, ponieważ chwila obecna prowadzi nas do owej niewykluczającej i w pełni inkluzyjnej przestrzeni istnienia. Klienci często stawiają opór teraźniejszości, gdyż wydaje im się, że jest ona związana z silnym dyskomfortem i doświadczeniem wykluczenia. Tymczasem uważność, wraz ze

8 Por. F. Jalics, Rekolekcje kontemplatywne, tłum. J. Bolewski, Kraków 2007, s. 47-73.

9 Por. D. E. Rizzetto, Przebudź się ku temu, co czynisz, tłum. O. Córnicka, S. Piela, Bielsko-Biała 2007, s. 41. 
świadomością ciała i oddechu, wprowadza do nowego sposobu doświadczania, w którym sytuacja życiowa ustępuje miejsca życiu. W pracy socjalnej bardzo często skupiamy się na sytuacji, w której klient się znalazł - jego pozycji materialnej, warunkach mieszkaniowych czy relacjach sąsiedzkich. Już na początku ustawy o pomocy społecznej znajdujemy zapis, że „pomoc społeczna jest instytucją polityki społecznej państwa, mającą na celu umożliwienie osobom i rodzinom przezwyciężanie trudnych sytuacji życiowych" (art. 2) ${ }^{10}$. W ten sposób często tak bardzo koncentrujemy się na sytuacji życiowej, że umyka nam życie. Istnienie jest bowiem przestrzenią w pełni inkluzyjną - z każdym oddechem jesteśmy, nawet gdy sobie tego nie uświadamiamy. Dlatego Eckhart Tolle, jeden z ciekawszych współczesnych nauczycieli uważności, radzi swojemu uczniowi: „Zapomnij na chwilę o sytuacji życiowej i skup się na życiu"11.

Odniesienie do cudu samego życia, które jest nam dane w chwili obecnej, nie jest jakimś wspaniałym wynalazkiem współczesności. Na kartach Ewangelii odnajdujemy istotne z punktu widzenia pracy socjalnej przesłanie Jezusa z Nazaretu:

Dlatego powiadam wam: nie troszczcie się zbytnio o swoje życie, o to, co macie jeść i pić, ani o swoje ciało, czym się macie przyodziać. Czyż życie nie znaczy więcej niż pokarm, a ciało więcej niż odzienie? Przypatrzcie się ptakom w powietrzu: nie sieją ani żną i nie zbierają do spichrzów, a Ojciec wasz niebieski je żywi. Czyż wy nie jesteście ważniejsi niż one? Kto $\mathrm{z}$ was przy całej swej trosce może choćby jedną chwilę dołożyć do wieku swego życia? A o odzienie czemu się zbytnio troszczycie? Przypatrzcie się liliom na polu, jak rosną: nie pracują ani przędą. A powiadam wam: nawet Salomon w całym swoim przepychu nie był tak ubrany jak jedna z nich. Jeśli więc ziele na polu, które dziś

10 Ustawa z dnia 12 marca 2004 r. o pomocy społecznej (Dz.U. z 2004 Nr 64 poz. 593).

11 E. Tolle, Potęga teraźniejszości, tłum. M. Kłobukowski, Łódź 2010, s. 75. 
jest, a jutro do pieca będzie wrzucone, Bóg tak przyodziewa, to czyż nie tym bardziej was, małej wiary? [...] Nie troszczcie się więc zbytnio o jutro, bo jutrzejszy dzień sam o siebie troszczyć się będzie. Dosyć ma dzień swojej biedy ${ }^{12}$.

W tym fragmencie Ewangelii Jezus zwraca uwagę na to, że pod powierzchnią naszych codziennych zmartwień znajduje się coś, co powinno nas zachwycić - życie, które jest pełnią. Nie trzeba się o nią troszczyć, bo z natury niczego jej nie brakuje. W tej ukrytej pełni naszego życia znajduje się najwyższe piękno - większe niż piękno królewskiego przepychu. Za tę pełnię nie musimy płacić ani nie musimy na nią zasługiwać - po prostu w niej uczestniczymy, jest nam dana jako dar. Dlaczego zatem odcinamy się od pierwotnego piękna życia, które dzieje się przy naszym udziale? Wydaje się, że szczególnie w praktyce pracy socjalnej z osobami uzależnionymi doświadczenie pełni istnienia może być niezwykle przydatne. Istotne rozwiązania w tej kwestii przynoszą badania Stanleya Blocka, amerykańskiego psychiatry i psychoanalityka, którym przyjrzymy się nieco bliżej.

\section{Mind-Body Bridging}

Świadomość oddechu i zanurzenie w teraźniejszości prowadzą w pracy socjalnej do zmiany perspektywy patrzenia na problem uzależnienia. Zmienia się wówczas filtr percepcyjny, przez który klient i pracownik socjalny spoglądają na sytuację problemową. Zmiana perspektywy możliwa jest wówczas, gdy podejmuje się regularną

Mt 6, 25-30. 34 [cytaty z Biblii za: Biblia Tysiąclecia, wyd. IV, Poznań 2003]. W greckim oryginale na określenie życia pojawia się $\psi v x \tilde{n}-p s y c h e . W$ innych miejscach Biblii ten termin oznacza także duszę (Mt 12, 18; 22, 37; 26, 38). W kontekście terminu psyche jeszcze bardziej adekwatne wydaje się odniesienie do oddechu i świadomości. 
formalną praktykę oraz nieformalne praktyki uważności. Kwintesencją zastosowania mindfulness w pracy socjalnej wydaje się metoda Mind-Body Bridging, którą stworzył Stanley Block. Dzięki jego badaniom możemy rzucić nowe światło na znaczenie pytania „Kim jestem?" w pracy socjalnej.

Metoda Mind-Body Bridging opiera się na dostrojeniu ciała i umysłu w taki sposób, aby umożliwić naturalny proces odzyskiwania równowagi wewnętrznej. Stanley Block w swojej pracy terapeutycznej na co dzień spotykał się z bólem, traumą i innymi postaciami ludzkiego nieszczęścia. Jednocześnie był przekonany, że każdy - bez względu na to, w jakiej sytuacji się znajduje - uczestniczy w pewnej najgłębszej rzeczywistości, którą nazwał Źródłem. Block pisze: „każdy z nas jest $\mathrm{z}$ tym Źródłem połączony jak promień ze słońcem"13. Pewnego dnia jednak odkrył, jak wielki potencjał terapeutyczny przynosi uważne słuchanie prostego dźwięku, takiego jak szmer lodówki. Siedząc w fotelu, doświadczył, jak głęboki spokój daje zwykłe słuchanie dźwięku. Następnie spostrzegł, że gdy pojawiały się myśli, szmer lodówki przestawał być słyszalny: „moje skupione na mnie samym myśli zatykały moje uszy"14.

Możemy wyróżnić następujące kluczowe elementy proponowanej przez Blocka metody:

1) każdy człowiek uczestniczy w pełni, a poczucie uszkodzenia (damaged) jest iluzoryczne;

2) największy potencjał terapeutyczny ma uważność (mindfulness), która opiera się na:

a) „powrocie do zmysłów”, czyli zwracaniu uwagi na docierające do nas bodźce, zwłaszcza słuchowe i dotykowe;

b) dekonstrukcji myśli, która polega na ich uważnym obserwowaniu i „rozbrajaniu” ich toksycznego charakteru. 


\section{Pełnia i iluzja „uszkodzenia”}

Stanley Block pisze:

Prawdziwy ty jesteś niepodobny do jakichkolwiek wyobrażeń, cudownie rozległy, kompletny, połączony ze Źródłem i z wszystkim, co istnieje. Jesteś w pełni obecny w każdej chwili ${ }^{15}$.

Pełnia, w której człowiek uczestniczy, charakteryzuje się brakiem oddzielenia - człowiek stanowi jedność z otaczającą go rzeczywistością. W tym doświadczeniu istota ludzka nie jest oddzielona od Źródła, a więc od Absolutu - zasady istnienia. Pełnia, o której tu mowa, jest bezwarunkowa, uzależnienie nie jest w stanie jej przekreślić. Bez względu na to, czy człowiek emocjonalnie doświadcza pełni, czy też nie, jest w niej zanurzony, gdyż stanowi ona najgłębszy poziom bytu jedność wszystkiego, co istnieje.

Owa pełnia i jedność ze Źródłem przywodzą na myśl pisma mistyków różnych tradycji, którzy żyli w głębokiej jedności z Absolutem. Jednocześnie opis owej pełni bardzo kontrastuje z rzeczywistością, z którą stykają się pracownicy socjalni w swojej codziennej praktyce. Korzystający z pomocy społecznej klienci nadużywający substancji psychoaktywnych najczęściej mają bardzo głęboko zinternalizowane poczucie licznych braków, które są ich udziałem. Bieda, uzależnienie, bezdomność czy choroba są przeżywane jako defekt i poważna dysfunkcja. Podobnie swoją sytuację określali pacjenci Stanleya Blocka, którzy przychodzili do niego, oczekując, że ten ich „naprawi”. Block dostrzegł, iż elementem, który pojawia się w opowieściach wszystkich pacjentów, jest poczucie uszkodzenia (damaged $)^{16}$.

16 Por. S. Block, Powrót do zmysłów, dz. cyt., s. 30. 
Poczucie uszkodzenia jest głęboko wpisane w świadomość borykających się z uzależnieniem klientów pracowników socjalnych. Stanley Block twierdzi jednak, że w swej istocie to poczucie uszkodzenia ma charakter iluzji, którą w ciągu swojego życia starannie podtrzymujemy poprzez wewnętrzne narracje, ciągle przetaczające się przez nasz umysł. „Rodzice mnie nie kochali”, „Jestem nieudacznikiem”, „Nikt nie skrzywdził mnie tak jak on” - te wszystkie wewnętrzne dialogi stają się fundamentem poczucia „uszkodzenia” - „Skoro jestem bezdomny, chory i uzależniony, to jestem nikim".

Metoda Mind-Body Bridging proponuje nowe podejście do tego typu wewnętrznych narracji. Jako punkt wyjścia przyjmuje, że człowiek jest pełnią - połączony ze Źródłem. W swej najgłębszej istocie obojętnie, gdzie się znajdujemy w społecznej hierarchii - wszyscy uczestniczymy w cudzie istnienia i pełni. Poczucie uszkodzenia jest natomiast narzucone przez tzw. układ tożsamości. Block pisze, że układ tożsamości, podobny do układu krążenia czy oddechowego, nadaje wewnętrzną dynamikę myślom. Mają one charakter egocentryczny i służą realizacji naszych planów. Układ tożsamości pełni ważną funkcję w naszym funkcjonowaniu w strukturze społecznej. Jednak bardzo często działanie tego układu sprawia, że jesteśmy odcięci od Źródła. Szczególną rolę pełnią w tym procesie tzw. wymogi. Mogą one przybierać różną formę, np. „Powinienem zrobić karierę”, „Czemu nie wezmę się w garść?”, „Powinienem robić wszystko bezbłędnie"17. Jeśli nie zostaną zaspokojone, wówczas doświadczamy napięcia, strachu i złego samopoczucia ${ }^{18}$. Nadaktywność układu tożsamości sprawia, że mamy poczucie, iż nasza jaźń jest uszkodzona. Klient wówczas postrzega siebie wyłącznie przez pryzmat swoich traum, zranień i biedy.

17 Por. S. Block, Powrót do zmysłów, dz. cyt., s. 33.

18 Por. S. Block, Powrót do zmysłów, dz. cyt., s. 27. 
W procesie dostrojenia ważne jest, aby wprowadzić układ tożsamości w stan spoczynku. Gdy klient rozpozna wymogi, które stały się częścią jego układu tożsamości, będzie ich świadomy i nie pozwoli, aby nim kierowały; wówczas „do głosu dojdzie naturalnie i swobodnie funkcjonująca jaźn'" ${ }^{19}$. Wskazówka Stanleya Blocka jest następująca: „najważniejsze byś pamiętał, że nie istnieje coś takiego jak uszkodzona jaźń - naprawdę nie jesteś uszkodzony. Jesteś kompletny, jesteś całością"20. Wydaje się, że jest to kluczowe przesłanie, jakie pracownik socjalny może przekazać swojemu klientowi zmagającemu się z uzależnieniem.

Układ tożsamości wraz z wewnętrznymi rozważaniami na temat tego, kim jesteśmy i czego nam brakuje, odcina nas od rzeczywistości. Stajemy się nieczuli na zmysłowe bogactwo otaczającego nas świata. Nie dostrzegamy mnogości niezwykłych zjawisk, których na co dzień jesteśmy świadkami - słońca, chmur, odgłosów ulicy, śpiewu ptaków czy dotyku przedmiotów. Tym samym odcinamy się od tego, kim naprawdę jesteśmy.

Myśli, które posiadamy, pojawiają się i znikają zupełnie spontanicznie. Są pozytywne, negatywne lub neutralne i przypominają chmury przesuwające się po niebie. Jednak nie zawsze tak jest. Często myśli o tym, że „do niczego się nie nadaję” bądź „moje życie to pasmo porażek" utrzymują się dłużej. Według Stanleya Blocka zawdzięczamy to pewnym wewnętrznym dynamikom układu tożsamości: depresorowi i fikserowi. Block pisze: „Depresor przechwytuje twoje naturalne myśli, by utrwalić poczucie uszkodzenia. Fikser przechwytuje twoje naturalne myśli, próbując usunąć poczucie uszkodzenia"21.

W pracy socjalnej opartej na uważności celem jest przerwanie tego błędnego koła depresora czy fiksera poprzez zaobserwowanie

S. Block, Powrót do zmysłów, dz. cyt., s. 33.

S. Block, Powrót do zmystów, dz. cyt., s. 33-34.

S. Block, Powrót do zmysłów, dz. cyt., s. 51. 
wymogów. Wystarczy je dostrzec i oznaczyć jako pochodzące od wewnętrznej dynamiki depresora. W ten sposób następuje neutralizacja ich toksycznego charakteru. Gdy pojawią się wymogi zmierzające do „naprawienia” obecnej sytuacji, należy oznaczyć te myśli jako pochodzące od wewnętrznej dynamiki fiksera.

Czy wobec tego praca socjalna oparta na uważności zmierza do powstrzymania się od działania i zatopienia w niemej kontemplacji myśli? Oczywiście, że nie. Jednak w ramach metody Mind-Body Bridging przyjmujemy, że umysł w sposób naturalny stwarza warunki do rozwiązania problemu. Dokonuje się to w procesie dostrojenia ciała i umysłu, gdy układ tożsamości obejmujący depresor i fikser znajduje się w stanie spoczynku. Założeniem tej metody jest bowiem to, że każdy - zarówno klient, jak i pracownik socjalny - nie jest „uszkodzony”, lecz w niezwykły sposób uczestniczy w pełni - połączony ze Źródłem istnienia. Owo dostrojenie u pracownika socjalnego jest również niezbędne. W dniu, w którym klient przekroczył próg lokalnej organizacji pomocowej, pracownik socjalny mógł mieć głowę pełną następujących myśli: „nikt mnie nie szanuje”, „moja praca nie ma sensu”, które możemy określić jako pochodzące od depresora. Jednak w trakcie spotkania z klientem uruchomił się fikser - „muszę jej pomóc nie spaść na dno”. W taki sposób ten taniec depresora i fiksera sprawia, że zarówno klient, jak i pracownik socjalny łatwo wpadają w pułapkę układu tożsamości. Rozwiązaniem tej sytuacji jest „powrót do zmysłów”.

Dziś dotknąłeś bielizny, skarpetek, butów, bluzy, spodni, noża, widelca, papieru, długopisu, klamki, kluczy, krzesła, mydła, ręcznika. To zaledwie cząstka codziennej dawki bodźców zmysłowych. Jak wielu spośród tych tysięcy doznań byłeś świadomy ${ }^{22}$

- takie pytanie warto zadać klientowi pracy socjalnej. „Powrót do zmysłów” to świadomość tego, na co patrzymy, tego, czego słuchamy, 
świadomość doznań w ciele i myśli. Nasz klient ma dostęp do całego bogactwa przeżyć, które są jego czy jej udziałem każdego dnia. Metoda Mind-Body Bridging zastosowana do pracy socjalnej pokazuje, że istnieje cała gama doznań i codziennych doświadczeń (jest ich naprawdę mnóstwo!), z których klient nie jest wykluczony, wręcz przeciwnie - jako mieszkaniec Ziemi jest zaproszony do pełnego odczuwania. W pracy socjalnej opartej na uważności zwracamy uwagę na proste, codzienne czynności, które umykają uwadze naszego klienta. Przykładem może być branie prysznica. Zamiast myśleć o swojej tragicznej sytuacji związanej z uzależnieniem, klient może skupić się na dotyku wody, wykonującej swój taniec po całym ciele, na łagodnym dotyku palców, wcierających szampon we włosy, bądź też na zapachu mydła - i w ten sposób całym ciałem wrócić do rzeczywistości. Podobnie rzecz się ma z odbieraniem telefonu. Oddajmy głos twórcy metody dostrojenia:

Kiedy następnym razem zadzwoni telefon, weź głęboki oddech, wsłuchaj się w inne dźwięki w pomieszczeniu, zwróć uwagę na pozycję swojego ciała i doznania w ciele, a potem pójdź w stronę telefonu. Świadome odbieranie telefonu jest cudowną praktyką dostrojenia ${ }^{23}$.

Również w sklepie można „powrócić do zmysłów”. Zamiast irytacji z powodu przedłużającego się czasu oczekiwania w kolejce, możemy wsłuchać się w odgłosy, które dobiegają do naszych uszu zasłuchani w muzykę z radiowęzła, płaczące dziecko, skaner informujący o odczytaniu ceny towaru będziemy jednością z otaczającą nas rzeczywistością. Możemy wówczas również doświadczyć naszego ciała i jego reakcji - zmęczonych nóg, uczucia pragnienia czy stóp opartych o podłoże $e^{24}$. 
W pracy socjalnej opartej na uważności staramy się podkreślić fundamentalne elementy świata, z których klient nie jest wykluczony. Taką częścią rzeczywistości jest np. prawo grawitacji. Oddziałuje ono na każdego z nas, bez względu na posiadany dochód. To na pozór banalne stwierdzenie pokazuje, jak wiele umyka naszej uwadze w codziennej walce $\mathrm{z}$ wykluczeniem. Tymczasem harmonijna świadomość grawitacji może przywrócić nam poczucie wewnętrznej równowagi.

"Powrót do zmysłów” jako narzędzie radzenia sobie z uzależnieniem opiera się na kilku elementach. Po pierwsze, warto wsłuchiwać się w odgłosy otoczenia. Słuchanie dźwięków pędzącego tramwaju lub stukotu obcasów kobiety idącej przed nami pozwala wejść w kontakt z otaczającym światem. Po drugie, warto słuchać doznań w ciele. Jakie są odczucia płynące z pleców, z karku, ze stóp albo jak kołnierzyk dotyka szyi? - to wszystko buduje relacyjny stosunek do świata. Co widzisz? Co czujesz? Jakiego zapachu doświadczasz? Czego dotykasz? Ważne, aby nie angażować się przy tym zbytnio w proces myślowy, nie osądzać, lecz pozwolić temu, co widziane i słyszane, być. Po trzecie, cenna jest umiejętność obserwacji wewnętrznych opowieści. Mózg bowiem nieustannie produkuje „wewnętrzny kanał telewizyjny”, w którym coś się dzieje. Warto go obserwować.

Niezwykle pożytecznym ćwiczeniem dla praktyki pracy socjalnej jest „nazywanie myśli”. Jego cel stanowi uświadomienie sobie, że myśl nie ma jakiegoś niezwykłego statusu ontologicznego, ale jest tylko myślą. Ma to szczególnie duże znaczenie w pracy socjalnej z osobami, którym w związku ze swoim uzależnieniem $\mathrm{z}$ trudem przychodzi panowanie nad gniewem i destrukcyjnymi zachowaniami. Stanley Block podaje przykład pacjenta skazanego za pobicie kierowcy innego auta, z którym miał stłuczkę. Gdy następnym razem ów pacjent, siedząc za kierownicą, myślał „Zepchnę tego drania do rowu”, przekształcał to w sformułowanie: „Mam myśl: zepchnę tego 
drania do rowu"25. Ta z pozoru niewielka zmiana zupełnie zmienia postrzeganie funkcjonowania naszego umysłu. Inny z pacjentów Blocka stwierdził z niezwykłą trafnością: „Spójrz na ten świat. To myśli powodują, że zabijamy się nawzajem"26. Uświadomienie sobie myśli wprowadza układ tożsamości w stan spoczynku i wraz ze zwróceniem uwagi na doznania zmysłowe przywraca równowagę.

Georg Wilhelm Friedrich Hegel przedstawił w Fenomenologii ducha niezwykle ciekawą dialektykę pana i niewolnika. Pan sprawuje władzę nad niewolnikiem, jednak przez to ma jedynie zapośredniczony kontakt z rzeczą, która jest owocem pracy niewolnika. Niewolnik zaś, choć poddany panu, kształtuje rzeczywistość bezpośrednio, formuje ją swoją pracą ${ }^{27}$. W tym dialektycznym procesie następuje paradoksalne stopniowe odwrócenie ról: pan staje się coraz mniej wolny, gdyż oderwany od pracy jest zależny od dzieła innych. Niewolnik zaś stopniowo poprzez pracę przekracza swoją alienację i staje się coraz bardziej wolny. Dialektyka ta pokazuje, jak paradoksalne są podziały i stratyfikacje społeczne. W pracy socjalnej często powielamy schematy myślowe, że wyższa klasa średnia żyje pełnią życia i korzysta z jego niezwykłych dobrodziejstw, a jedyne, co mogą zrobić klienci borykający się z uzależnieniem, to „funkcjonować”, jeśli oczywiście uda im się to osiągnąć.

Tymczasem Hegel pokazuje pracownikom socjalnym, że to, co stanowi fundament niewoli (w Fenomenologii ducha to praca), jest zarazem środkiem wyzwolenia. Do podobnych wniosków dochodzi Stanley Block, gdy twierdzi:

27 Por. G. W. F. Hegel, Fenomenologia ducha, t. I, tłum. A. Landman, Warszawa 2010, S. 117. 
Twój układ tożsamości jest dla ciebie błogosławieństwem. Naprawdę. Za każdym razem, kiedy dostrzegasz jego istnienie, znajdujesz jednocześnie dojście do swojej prawdziwej jaźni i do naturalnego, swobodnego działania ${ }^{28}$.

Rzeczywistość jest bowiem paradoksalna: to, co jest z pozoru przekleństwem (niewolnicza praca, układ tożsamości), staje się drogą do wolności.

Paradoksalnie okazuje się, że klienci pomocy społecznej są bliżej życia niż wielcy kapitaliści i właściciele przedsiębiorstw. To bowiem klienci, nierzadko od bardzo długiego czasu borykający się z uzależnieniem, często doświadczają głodu, ubóstwa, niebezpieczeństwa śmierci - tego wszystkiego, co „nagie życie” przynosiło ludziom od pokoleń. Posiadacz kapitału może się rozkoszować dobrami ${ }^{29}$, jednak czy w tym doznaje „nagiego życia” z całą jego brutalnością, ale zarazem również i ukrytym pięknem? Zgodnie z Heglowską dialektyką to właśnie wykluczeni mają „klucz” do rzeczywistości.

Doświadczenie i droga życiowa Franciszka z Asyżu wydają się potwierdzeniem tej przedziwnej dialektyki. Franciszek, poznając radykalne ubóstwo i wyrzekając się posiadania, rozkoszuje się dobrami i układa Pieśń słoneczną, w której zachwyca się bratem Słońcem

[...] przez które staje się dzień, siostrą wodą, która jest pożyteczna, pokorna, cenna i czysta, oraz matką naszą Ziemią, która nas żywi i utrzymuje, wydając wszelki owoc, barwne kwiaty i zioła ${ }^{30}$.

Uważność jest najlepszą nauczycielką takiego spojrzenia i niesie w sobie rewolucyjny potencjał wyzwolenia dotychczasowego „nie-

S. Block, Powrót do zmysłów, dz. cyt., s. 172.

Por. G. W. F. Hegel, Fenomenologia ducha, dz. cyt., s. 117.

Franciszek z Asyżu, Pieśń słoneczna albo pochwały stworzeń, [w:] Pisma św. Franciszka z Asyżu, tłum. K. Ambrożkiewicz, Warszawa 1982, s. 250-251. 
wolnika” z kajdan, które w efekcie okazują się jedynie iluzją wynikającą ze zbyt wąskiego postrzegania rzeczywistości.

Praktykowanie uważności może być niezwykle skuteczne w walce z uzależnieniem. Zalecenie medytacji, które jest ważną częścią programu 12 kroków, staje się dzięki praktyce mindfulness integralną częścią zwykłych czynności. Przede wszystkim do praktykowania uważności nie są potrzebne dodatkowe środki finansowe czy programy przeciwdziałające wykluczeniu. Uważność jest bowiem prosta i dostępna dla każdego, bez względu na wysokość dochodu. Szczególnie metoda Mind-Body Bridging sprawia, że uważność przenika do każdej sekundy życia. Na uwagę zasługują zwłaszcza narzędzia pracy z tzw. układem tożsamości, które w kontekście wolności od uzależnienia mogą być niezwykle pomocne. Osoby nadużywające substancji psychoaktywnych często mają poczucie, że czegoś im brakuje, że są gorsze i w jakiś sposób „uszkodzone” przez uzależnienie. Uświadomienie sobie uzależnienia jest bardzo ważne i stanowi integralny element terapii, jednak autodestrukcyjne myśli o własnym „uszkodzeniu” nie przyczyniają się do zdrowienia. W tym kontekście kluczowe jest zwrócenie uwagi klienta na Źródło, z którym jest połączony - bez względu na to, w jakiej jest sytuacji życiowej. Wszyscy bowiem uczestniczymy w pełni - pełni człowieczeństwa, a z niej żadne uzależnienie nie jest w stanie nas wykluczyć. 